Original Research Paper

\title{
Biotic and Abiotic Factors of Sperm nDNA Fragmentation in Farm Animals
}

\author{
${ }^{1}$ Baylar Iolchiev, ${ }^{1}$ Natalya Volkova, ${ }^{1}$ Pavel Klenovitskiy, ${ }^{1}$ Vugar Bagirov, \\ ${ }^{2}$ Neilia Khusnetdinova, ${ }^{1}$ Prytkov Yuri, ${ }^{3}$ Anna Tadzhieva and ${ }^{1}$ Anastasia Silanteva \\ ${ }^{1}$ Federal Research Center for Animal Husbandry Named after Academy Member L.K. Ernst, \\ Dubrovitsy 60, Podolsk Municipal District, Moscow Region, 142132 Russia \\ ${ }^{2}$ Skryabin, Academy of Veterinary Medicine and Biotechnology, 23, Scryabin Str., 109472 Moscow, Russia \\ ${ }^{3}$ Peoples' Friendship University of Russia (RUDN University), 6, Miklukho-Maklaya Str., Moscow, 117198, Russia
}

\author{
Article history \\ Received: 20-01-2021 \\ Revised: 10-03-2021 \\ Accepted: 11-03-2021 \\ Corresponding Author: \\ Baylar Iolchiev \\ Federal Research Center for \\ Animal Husbandry named after \\ Academy Member L.K. Ernst, \\ Dubrovitsy 60, Podolsk \\ Municipal District, Moscow \\ Region, 142132 Russia \\ Email: baylar1@yandex.ru
}

\begin{abstract}
Infertility and subfertility are among the global challenges of our time. Fertility in livestock farming is not only biologically important, it is also economically important. The aim of this study was to study the effect of these factors on sperm chromatin nucleus and to assess the impact of the fragmentation index degree on bull reproductive performance. The influence of abiotic factors such as ambient temperature, the level of geomagnetic activity and the biotic factorinfectious diseases of male reproductive organs - was studied. At high ambient temperatures $\left(28-30^{\circ} \mathrm{C}\right)$, the proportion of sperm with damaged DNA increased by $70 \%$ compared to temperatures below $15^{\circ} \mathrm{C}$. A Multivariate Analysis Of Variance (MANOVA) confirmed the influence of the geomagnetic activity factor on the degree of nuclear DNA fragmentation in bull sperm cells (level $\mathrm{p}<0.05$ ). During the summer period, on days with increased geomagnetic activity, the Nuclear DNA fragmentation index in the samples studied was $20.5 \%$. In some of the samples studied, this index exceeded $38 \%$ and the coefficient of variation for this index reached $44 \%$. The proportion of sperm cells with abnormal movement also increased during geomagnetic activity. The content of such sperm cells reached $9.1 \%$ in bull semen ejaculates obtained during the winter period. More than $12 \%$ of sperm had non-progressive movement in summer semen obtained with a $\mathrm{K}$-index $\geq 5.0$, which was $83.8 \%$ higher than with a $\mathrm{K}$-index $\leq 1.0$. High geomagnetic activity and temperature and infection of the reproductive organs lead to pathological changes in spermatozoa, an increase in the proportion of spermatozoa with damaged nuclear DNA and a decrease in fertility.
\end{abstract}

Keywords: Bulls, Fertility, DNA Fragmentation, Geomagnetic Activity, Ram, Semen

\section{Introduction}

The main function of sperm cells is not only to deliver male genetic material to the egg, its fertilization and stimulation of embryo development, but also to ensure the development of a complete embryo ( $\mathrm{Li}$ and Lloyd, 2020; Aitken et al., 2013). Fertility is one of the global problems of our time, more than $15 \%$ of married couples around the world face this problem, it is also characteristic of animal breeding, about $25 \%$ of bulls are subfertile or infertile (Kim, 2018). The diagnosis of male fertility is based on classical methods of analysis, in accordance with the criteria of the World Health Organisation (Santi et al., 2018). The fertility tests used do not provide complete information on the biological completeness of sperm cells and do not allow the evaluation of all structural units. The prognosis of fertility and the results of the use of assisted reproductive technologies based on such tests cannot be highly accurate and they do not allow differentiation between fertile and subfertile individuals (Björndahl et al., 2016; Cho and Agarwal, 2018). Additional tests are used to 
assess the fertility of males. Special attention is paid to the condition of genetic material in sperm in order to determine their competence (Shamsi et al., 2011). Sperm nuclear DNA fragmentation and denaturation has a negative impact on their fertility, embryo development and may also cause idiopathic infertility (Agarwal and Said, 2003). In subfertile male individuals, the DNA fragmentation index is higher than in fertile individuals. Fertilization of sperm oocytes with damaged chromatin DNA may be a cause of genetic disease in offspring (Zini et al., 2001). Modern assisted reproductive technology makes it possible to successfully fertilize oocytes with sperm with low biological integrity, which raises questions about the feasibility of performing DNA fragmentation tests in sperm chromatin (Twigg et al., 1998). Numerous studies have been conducted on the relationship between fertility and DNA fragmentation in sperm cells (Osman et al., 2015; Choi et al., 2017). The methods and protocols of analysis differ significantly, which is the reason why there is a lack of reliable information about the impact of genetic material fragmentation in sperm DNA on male fertility (Simon et al., 2017; Deng et al., 2019; Liang et al., 2019). Determining the fragmentation index to predict fertility is important, including for animals (Ortiz et al., 2017; Evenson, 2016; Esteves, 2016; Ozkosem et al., 2015). A high fragmentation index has a negative impact on reproductive performance not only when artificial insemination or other assisted reproductive techniques are used, but also when conception is natural (Zini, 2011). Studies show that if the fragmentation index is higher than $30 \%$, natural conception is not possible (Evenson et al., 2002). High levels of sperm DNA fragmentation can lead to early abortion of pregnancy (Carrell et al., 2003). In order to achieve high performance, sperm cell with intact DNA must be used for fertilization using assisted reproductive technology. This is especially important for subfertile individuals. The use of sperm with intact DNA is also necessary for the cryopreservation, as they are subjected to different technological influences (Kumar et al., 2019; Lusignan et al., 2018). The appearance of various DNA damage may be due to the age of individuals, infectious diseases, chronic or acute inflammatory disorders, environmental pollution, temperature stress, irradiation, incomplete apoptosis, as well as sperm storage conditions, technology for freezing and thawing sperm (Cankut et al., 2019; Evgeni et al., 2015). One of the main factors causing sperm DNA damage is male genital tract infection (Askienazy-Elbhar, 2005). The products of infected cells contain active forms of oxygen, which cause damage to the DNA structure and result in chromatin ruptures (Sakkas and Alvarez, 2010). The DNA fragmentation index of sperm cells depends on the method of obtaining them. Male sex cells extracted from the epidermis, compared to ejaculated sperm, have a low chromatin DNA fragmentation index (Esteves et al., 2015). Cryopreservation of generative plasma, including sperm, is widely used in reproductive technology. Various methods and protocols are used for cryo-preservation of sperm cells, which differ in the rate at which the biomaterial is cooled and therefore they differ in the degree of DNA damage in sperm cells. Studies show that the smallest fragmentation index is found when using vitrification (Agha-Rahimi et al., 2014; Isachenko et al., 2019; Li et al., 2019). One of the natural abiotic factors affecting biological processes and living organisms is geomagnetic activity (Binhi and Prato, 2017; Begall et al., 2008). The mechanisms of magnetic storm influence on biological processes have not yet been fully studied, but the relationship of most physiological rhythms to geomagnetic activity is an undeniable fact (McCraty et al., 2017). High geomagnetic activity may lead to the disruption of transmission movement and reduce the buffer capacity of the antioxidant system. Some structural units in cells, such as mitochondria and endoplasmatic reticulum, are more sensitive to magnetic fields (Glinka et al., 2018). Electromagnetic fields have a significant influence on sperm motility and morphology (Li et al., 2010; Kumari et al., 2017). The study sperm quality problem is of great economic and biological importance, as the development of cryopreservation, artificial insemination and other assisted reproductive technologies opens up the possibility of inseminating the semen of one male of several tens of thousands of females. The use of poor quality semen can lead to many million losses. Reproductive indicators, including semen quality, depend on numerous exogenous and endogenous factors. The aim of this research was to study the influence of biotic and abiotic factors on the state of chromatin nuclear DNA in farm animals.

\section{Materials and Methods}

\section{Legal Requirements}

The protocols of experiments were approved by the Committee for Animal Care and Use of the L.K. Ernst Federal Research Centre for Animal Production in accordance with Decision No. 80 of the Council of the Eurasian Economic Commission of 10 November 2017 "On Approval of the Rules for Organization of Laboratory Testing during Veterinary Control (Supervision)".

\section{Animals and Diagram of Research}

The objects of research were Romanov rams ( $\mathrm{n}=$ $10)$, Romanov sheep and argali hybrids $(n=7)$ and bulls $(\mathrm{n}=78)$ of different breeds and directions of productivity (Table 1). The test animals were clinically healthy. We studied the effect of the nDNA fragmentation index on sperm motility on the state of 
acrosomes, the proportion of pathological forms of spermatozoa. The influence of ambient temperature and geomagnetic activity on the index of nDNA fragmentation of spermatozoa, on their activity, morphology and acrosome was studied. During the study period, the ambient temperature ranged from -13 to $+30 \mathrm{C}$. The $\mathrm{K}$-index characterizing the geomagnetic activity varied from 0 to 5 . To study the effect of a disease of the reproductive tract on the level of fragmentation, the quality of sperm of bulls diagnosed with balanoposthitis was studied. The diagnosis of animal disease was confirmed by PCR analysis.

2.3. Monitoring of geomagnetic activity was conducted according to the Institute of Earth Magnetism, ionosphere and radio wave propagation. N.V. Pushkova, Russian Academy of Sciences (http://geodata.izmiran.ru//.).

\section{Collection of Semen}

Semen from bulls was collected in a truncated artificial vagina with a disposable sterile polyethylene sperm receiver. Two ejaculates were taken from each bull producer with an interval of 10-15 min. The ejaculates were diluted with the OptiXcell synthetic medium depending on their concentration. Cryopreservation of bull semen was carried out in straws.

Semen from rams was collected in an artificial vagina. "OVIXCell" (IMV TECHNOLOGIES) was used to dilute semen.

\section{Semen Analysis}

The collected ejaculate were evaluated on quantitative and qualitative indicators. The volume of obtained semen was determined.

\section{Sperm Motility}

Argus-CASA software was used to evaluate sperm activity. The sperm Velocity rates measured included the Curvilinear (VCL), Straight Line (VSL) and Average Path Velocity (VAP), linearity (LIN), Straightness (STR), wobble (WOB), Amplitude of Lateral Head displacement (ALH), Beat Cross Frequency (BCF) and Hyperactivity (HPA). Sperm, depending on the parameters, the movement is divided into classes: PR-Progressive Mobility; NP- NonProgressive mobility and IM-Immobility.

\section{DNA Sperm Fragmentation}

DNA sperm fragmentation was studied using the Halosperm® kit (INDAS laboratories, Madrid, Spain) in accordance with the protocol. The semen samples were diluted to a concentration of 20 million sperm per $\mathrm{ml}$. Then, spermatozoa were immersed in agarose microgel and spread on the slide. Samples were denatured with an acid and lysis solution, dehydrated and stained with Diffquick. Sperm with large halos (thicknesses that were similar or larger than the length of the smallest diameter of the core) and sperm with medium-sized halos (thickness greater than $1 / 3$ of the smallest diameter of the core and less than the smallest diameter of the core) were classified as 'spermatozoa having no fragmentation.

\section{Analysis Morphology and Acrosome}

Studying the condition of acrosome. The acrosomal integrity was studied using the Diahim-Diff-Quick differential staining (Borunova et al., 2017).

Sperm morphology was studied using electron microscopy (Bragina and Bocharova, 2014). Sperm morphology was classified according to the Krueger criterion.

\section{Statistical Analysis}

Analysis Of Variance (ANOVA) was used to determine the influence of the ambient temperature factor on the ram sperm DNA fragmentation index. The same analysis method was used to determine the effect of nuclear DNA fragmentation index on sperm motility and morphology of individual germ cell segments. ANOVA was used to evaluate the impact of bull reproductive disease on sperm DNA status. Multivariate Analysis Of Variance (MANOVA) was used to determine the impact of geomagnetic activity level (K-index) and ambient temperature in different seasons on sperm DNA fragmentation. We studied the effect of these fixed factors on the following variables: Sperm motility, content of pathological forms of sperm, sperm with intact acrosomes. The Scheffe's multiple comparison method was used to identify differences between groups. At $\mathrm{p}<0.001$ the differences were considered statistically highly significant, at $p<0.01$ and $p<0.05$ the differences were considered statistically significant.

Table 1: Study design

\begin{tabular}{lllll}
\hline Species & $n$ & Fixed factor & Fixed factor affecting DFI & A research variable \\
\hline Bos taurus taurus & 37 & $\begin{array}{l}\text { nDNA fragmentation index } \\
\text { in spermatozoa }\end{array}$ & $\begin{array}{l}\text { Sperm motility, the content of pathological forms } \\
\text { of spermatozoa, sperm count with intact } \\
\text { acrosome, bovine reproductive index }\end{array}$ \\
$\begin{array}{l}\text { Ovisaries } \\
\text { Bos taurus taurus }\end{array}$ & 17 & 35 & $\begin{array}{l}\text { Ambient Temperature } \\
\text { Geomagnetic activity } \\
\text { and temperature } \\
\text { Reproductive Tract } \\
\text { infection }\end{array}$ & $\begin{array}{l}\text { Sperm nd fragmentation index, sperm motility, } \\
\text { the content of pathological forms of spermatozoa, } \\
\text { sperm with intactacrosome }\end{array}$ \\
$\begin{array}{l}\text { Sperm DNA fragmentation index, sperm motility, } \\
\text { the content of pathological forms of spermatozoa, } \\
\text { sperm count with intact acrosome, bovine } \\
\text { reproductive index }\end{array}$ & $\begin{array}{l}\text { nDNA fragmentation } \\
\text { index in spermatozoa }\end{array}$ & 4 & &
\end{tabular}




\section{Results}

\section{Effect of Environmental Temperature on Semen Quality}

During the summer period, when the ambient temperature rises to $28-30^{\circ} \mathrm{C}$, the content of motile sperm in freshly obtained ram semen reached $74.3 \pm 3.6 \%$ and the proportion of sperm with pathological morphology did not exceed $2.6 \%$. The sperm DNA fragmentation index in this case was $10.8 \pm 1.3 \%$ (Table 2 ).

The drop in ambient temperature to $15^{\circ} \mathrm{C}$ and below in autumn was accompanied by an improvement in the biological integrity of the ram's sperm cells. The content of motile sperm in the semen increased by $16.7 \%$ $(p<0.01)$ compared to the summer period. There was a decrease in the proportion of sperm cells with pathological morphology from 2.6 to $1.9 \%(p<0.001)$.

Semen obtained during the summer and autumn periods was used for cryopreservation with subsequent assessment of biological integrity of frozen-thawed semen. The content of progressively motile sperm in summer ejaculate samples was $36.0 \%$ and in autumn it was $43.6 \%$ (Table 3). The freeze-thaw cycle of semen was accompanied by an increase in the proportion of sperm with damaged nuclear DNA compared to newly obtained semen. In the autumn semen samples, the proportion of such sperm cells was $85 \%$ lower than in summer $(p<0.001)$.

\section{Relationship between Reproductive Performance and the Degree of Sperm Nuclear DNA Fragmentation}

The results of study on the integrity of frozen thawed bull semen showed that $18.9 \%$ of male DFI reached $15 \%$. In $8.1 \%$ of the examined individuals, this figure exceeded $50 \%$ (Table 4 ). The content of progressively motile semen in the studied ejaculates varied depending on the established DFI values. The proportion of PR sperm cells in semen samples with DFI below $15 \%$ was $44.6 \%$. With DFI of $16-49 \%$, this index decreased by $7.3 \%(p<0.001)$, with DFI over $50 \%$ by $12.5 \%$ ( $p<0.001)$. A high rate of cow pregnancy from the first insemination was found when bull semen with DFI of less than $15 \%$ was used. This indicator reached $47 \%$. With the use of sperm DFI semen $16-49 \%$, the insemination efficiency of cows was reduced by $15.8 \%(p<0.001)$, with the use of DFI semen over $50 \%$ - by $13 \%(p<0.001)$.

Table 2: Impact of environmental temperature on ram semen quality

\begin{tabular}{llll}
\hline & & Ambient temperature \\
Dependent variable & Observations, $n$ & $-\mathrm{t} \geq 28-30^{\circ} \mathrm{C}$ & 17 \\
\hline Animals, $n$ & & 17 & $1.15 \pm 0.1$ \\
Volume, mL & 170 & $1.35 \pm 0.1$ & $86.7 \pm 2.5^{* *}$ \\
Sperm motility, $\%$ & 170 & $74.3 \pm 3.6$ & $1.9 \pm 0.1^{* * *}$ \\
Abnormal sperm morphology, $\%$ & 170 & $2.6 \pm 0.1$ & $6.2 \pm 0.8^{* *}$ \\
DNA fragmentation index (DFI), \% & 170 & $10.8 \pm 1.3$ & $92.2 \pm 3.6$ \\
Sperm with intact acrosome, $\%$ & 170 & $86.3 \pm 2.5$ & \\
\hline
\end{tabular}

$* p<0.05 ; * * p<0.01: * * * p<0.001$

Table 3: Quality of frozen and thawed semen obtained at different temperature conditions

\begin{tabular}{llll}
\hline & & Ambient temperature \\
Dependent variable & Observations, $\mathrm{n}$ & $-\mathrm{t} \geq 28-30^{\circ} \mathrm{C}$ & $\mathrm{t} \leq 15^{\circ}$ \\
\hline PR, \% & 170 & $36.0 \pm 1.8$ & $43,6 \pm 1.5^{* *}$ \\
$\mathrm{NP}, \%$ & 170 & $12.6 \pm 1.5$ & $5.7 \pm 0.9^{* *}$ \\
$\mathrm{IM} \%$ & 170 & $51.4 \pm 1.7$ & $50.7 \pm 1.1$ \\
Head pathology, \% & 170 & $50.6 \pm 1.6$ & $46.1 \pm 0.8^{*}$ \\
Pathology of the middle part, \% & 170 & $11.9 \pm 0.4$ & $12.3 \pm 0.3$ \\
Flagellum pathology, \% & 170 & $37.5 \pm 1.3$ & $41.6 \pm 1.6^{*}$ \\
Sperm with damagedn DNA, \% & 170 & $21.3 \pm 0.6$ & $11.5 \pm 0.8^{* * *}$ \\
\hline
\end{tabular}

PR -progressive motility; NP - non-progressive motility; IM- immobility

Table 4: Impact of fragmentation index of nuclear DNA on reproductive efficiency of bulls

\begin{tabular}{llll}
\hline Dependent variable & DFI $<15 \%$ & DFI $>16-49 \%$ & DFI $>50 \%$ \\
\hline Animals, $n$ & 30 & 4 & 3 \\
DFI, \% & $2.2 \pm$ & $27.8 \pm 1.6^{* * *}$ & $72.04 \pm 3.6^{* * *}$ \\
Sperm motility, $\%$ & $44.6 \pm 1.4$ & $37.2 \pm 1.7^{* * *}$ & $32.1 \pm 2.6^{* * *}$ \\
Pregnancy, $\%$ & $52.0 \pm 2.3$ & $36.0 \pm 1.4^{* * *}$ & $28.3 \pm 1.6^{* * *}$ \\
Pregnancy from the first insemination, $\%$ & $47.0 \pm 1.2$ & $31.2 \pm 0.9^{* * *}$ & $24.0 \pm 0.8^{* * *}$ \\
\hline
\end{tabular}

${ }^{*} p<0.05 ; * *_{p}<0.01: * * * p<0.001$; High geomagnetic activity and temperature and infection of the reproductive organs lead to pathological changes in spermatozoa, an increase in the proportion of spermatozoa with damaged nuclear DNA and a decrease in fertility 


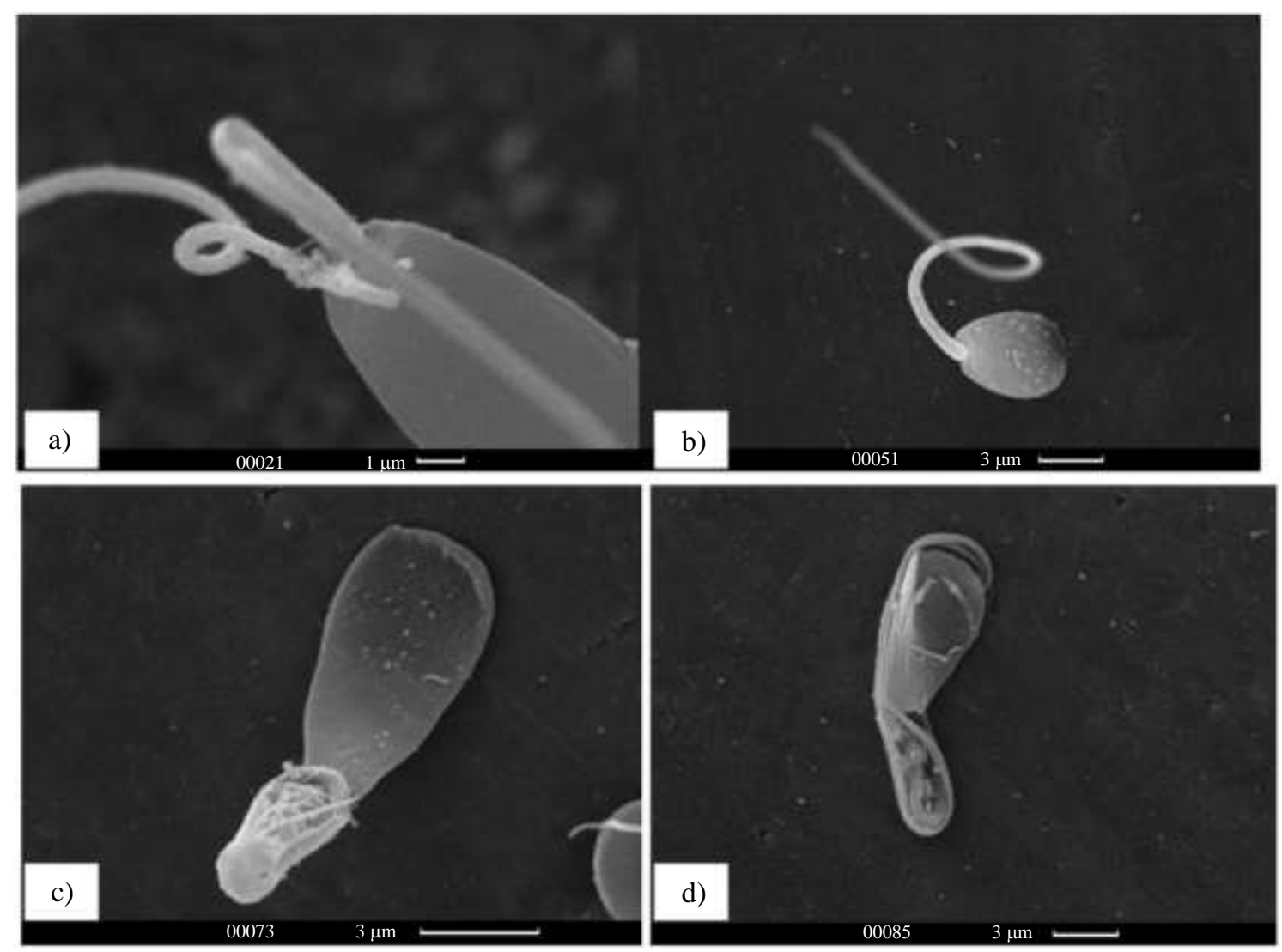

Fig. 1: Electron microscopy of bull sperm with pathological morphology

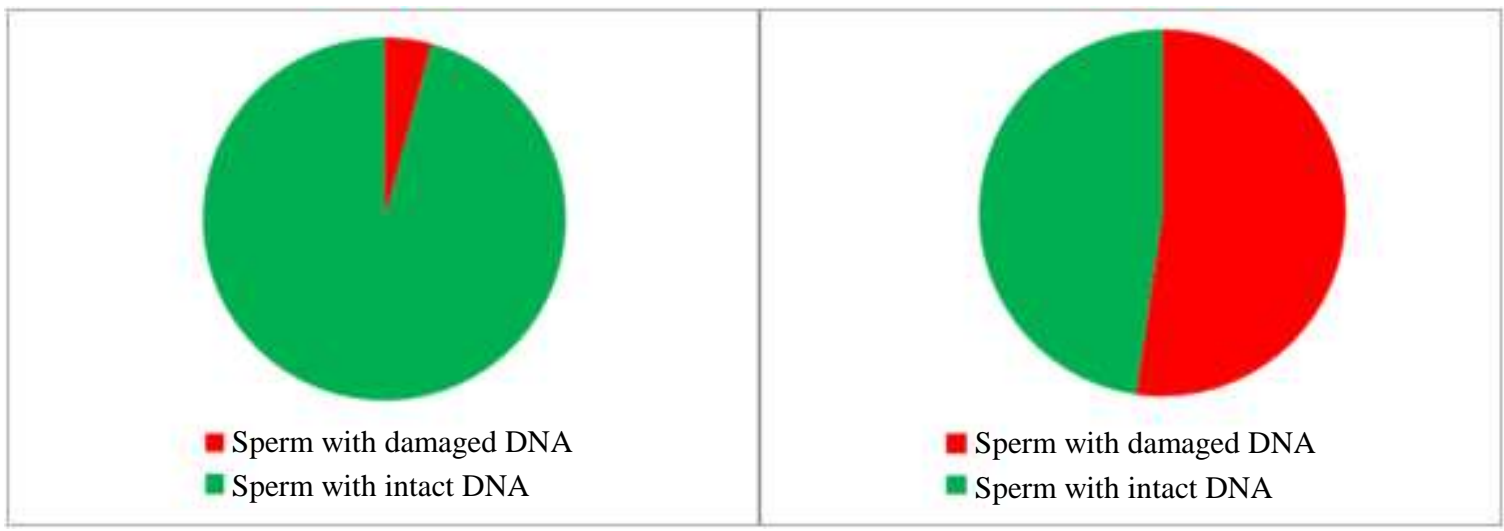

(a)

(b)

Fig. 2: Impact of reproductive organ infection on bull sperm DNA fragmentation index; (a) clinically healthy bulls; (b) bulls with infectious diseases of reproductive organs

\section{Effect of Geomagnetic Activity on Semen Quality}

The results of MANOVA have shown that the combination of environmental temperature factor and geomagnetic activity has a statistically significant effect on the activity and content of sperm cells with abnormal movement in the freshly received semen $(p<0.05)$. The minimum low temperature on geomagnetic activity days
(K-index $\geq 5.0$ ) was observed in February and dropped to $-13^{\circ} \mathrm{C}$. The proportion of sperm cell with pathological morphology in bull semen ejaculates obtained during this period was $7.8 \%$. Bull semen ejaculates obtained in a period with similar low surrounding temperatures but no high geomagnetic activity were also studied. The content of sperm cell in semen with pathological morphology in this case decreased by a factor of 1.5 compared to the 
period of high geomagnetic activity $(p<0.05)$. More than $50 \%$ of the detected pathologies in the sperm cells were caused by flagella anomalies. The results of electron microscopy in some forms of bull sperm pathology on days of geomagnetic activity was showed on Fig. 1.

During geomagnetic activity, the proportion of sperm cells with abnormal movement also increased. In bull semen ejaculates obtained during the winter period, the content of such sperm was $9.1 \%$. In summer semen obtained with a $\mathrm{K}$-index $\geq 5.0$, more than $12 \%$ of sperm had retrogressive movement, which was $83.8 \%$ higher than with a $\mathrm{K}$-index $\leq 1.0$.

\section{Influence of Bull Reproductive Organ Infections on Sperm Nuclear DNA Fragmentation Index}

One of the main biotic factors affecting the reproductive performance of male and female individuals is infectious diseases of the reproductive organs. The study results showed that the sperm DNA fragmentation index in clinically healthy bulls was $4.2 \pm 1.3 \%$. With infectious diseases of reproductive organs in these bulls, this index increased to $52.3 \pm 4.17 \%$ (Fig. 2).

\section{Discussion}

For the first time, a comprehensive study of the impact of biotic and abiotic factors on nuclear DNA fragmentation in sperm cells in farm animals was conducted. The influence of surrounding temperature as an abiotic factor on the degree of fragmentation of ram sperm DNA has been studied and the relationship between sperm quality and the degree of fragmentation of chromatin DNA has been analyzed. Data on the influence of ambient temperature on ram sperm quality are consistent with data from (Belkadi et al., 2017; Santos et al., 2015). High ambient temperatures can lead to disruption of individual sperm cells, reducing their biological integrity and to complete or partial infertility (Salces-Ortiz et al., 2015). The results of our research have shown that the proportion of sperm cells with damaged nuclear DNA increases in ram semen under high ambient temperatures. The our obtained data aboutthe negative impact of high temperature on DNA status corresponds to those obtained by (Pérez-Crespo et al., 2008). The negative effect of high temperature on sperm DNA integrity has been confirmed in other mammal species, such as mice (Fleming et al. 2004). An increase in temperature reduces the synthesis of the protein covering the sperm membrane, which, in turn, leads to the formation of morphologically abnormal spermatozoa. Sertoli cells are essential in spermatogenesis. High temperature damages Sertoli cells, reduces their number and disrupts the process of spermatogenesis. One of the damaging effects of high temperature is the activation of p53, which causes the cell cycle to stop. The high temperature of the scrotum cause condensation of nuclear chromatin. A number of studies have shown that one of the important abiotic factors affecting biological objects is geomagnetic activity (Binhi and Prato, 2017; McCraty et al., 2017). The results of MANOVA show that high geomagnetic activity leads to an increase in DNA fragmentation index in animal sperm. The influence of geomagnetic activity at the cellular level is explained by changes in the state and functions of cell membranes, a violation of transmembrane transport, the formation of free radical lipid oxidation products and a decrease in the buffer capacity of the antioxidant system. As a result of this process, reactive oxygen species are formed, which are one of the main factors causing nuclear DNA fragmentation in spermatozoa. In studies (Evenson et al., 2002) it has been established that natural conception is not possible with a sperm DNA fragmentation index of more than $30 \%$. The results of our studies show that cows can be fertilized with $50 \%$ of bull sperm DNA damage. It should be noted that the effectiveness of artificial insemination in this case was reduced by a factor of 2 and did not exceed $25 \%$. Inflammatory processes in infections of the reproductive organs lead to oxidative stress, which leads to an increase in the index of DNA fragmentation. Infection of the reproductive organs of bulls also increased the proportion of sperm with damaged DNA from 4.17 to $52.3 \%$.

\section{Conclusion}

The results of a study of the impact of various abiotic and biotic factors on the sperm quality of farm animals showed that there is a correlation between the sperm nuclear DNA fragmentation index and exogenous factors such as the surrounding temperature and geomagnetic activity. High geomagnetic activity results in an increased proportion of sperm with damaged nuclear DNA. During the period of high geomagnetic activity, there was a decrease in sperm movement and an increase in sperm content with abnormal morphology in the received bull semen ejaculates. Pathological changes in the flagellum area were most frequently observed. Infectious diseases of the male reproductive organs also contributed to sperm cell damage. An increase in the nuclear DNA fragmentation index resulted in a decrease in fertility.

\section{Funding}

The study was supported by Ministry of Science and Higher Education Russia (theme No. 0445-2021-0005).

\section{Author Contributions}

All authors have read and agreed to the published version of the manuscript. 


\section{Ethics}

This article is original and contains unpublished material. The corresponding author confirms that all of the other authors have read and approved the manuscript and no ethical issues involved.

\section{References}

Agarwal, A., \& Said, T. M. (2003). Role of sperm chromatin abnormalities and DNA damage in male infertility. Human Reproduction Update, 9(4), 331345. https://doi.org/10.1093/humupd/dmg027

Agha-Rahimi, A., Khalili, M. A., Nabi, A., \& Ashourzadeh, S. (2014). Vitrification is not superior to rapid freezing of normozoospermic spermatozoa: effects on sperm parameters, DNA fragmentation and hyaluronan binding. Reproductive Biomedicine Online, 28(3), 352-358. https://doi.org/10.1016/j.rbmo.2013.11.015

Aitken, R. J., Bronson, R., Smith, T. B., \& De Iuliis, G. N. (2013). The source and significance of DNA damage in human spermatozoa; a commentary on diagnostic strategies and straw man fallacies. MHR: Basic Science of Reproductive Medicine, 19(8), 475-485. https://doi.org/10.1093/molehr/gat025

Askienazy-Elbhar, M. (2005). Infection du tractus genital masculin: le point de vue du bactériologiste. Gynécologie Obstétrique \& Fertilité, 33(9), 691-697. https://doi.org/10.1016/j.gyobfe.2005.07.008

Begall, S., Červený, J., Neef, J., Vojtěch, O., \& Burda, H. (2008). Magnetic alignment in grazing and resting cattle and deer. Proceedings of the National Academy of Sciences, 105(36), 13451-13455. https://doi.org/10.1073/pnas.0803650105

Belkadi, S., Safsaf, B., Heleili, N., Tlidjane, M., Belkacem, L., \& Oucheriah, Y. (2017). Seasonal influence on sperm parameters, scrotal measurements and serum testosterone in OuledDjellal breed rams in Algeria. Veterinary World, 10(12), 1486. https://doi.org/10.14202/vetworld.2017.1486-1492

Binhi, V. N., \& Prato, F. S. (2017). Biological effects of the hypomagnetic field: An analytical review of experiments and theories. PLoS One, 12(6), e0179340. https://doi.org/10.1371/journal.pone.0179340

Björndahl, L., Barratt, C. L., Mortimer, D., \& Jouannet, P. (2016). 'How to count sperm properly': checklist for acceptability of studies based on human semen analysis. Human Reproduction, 31(2), 227-232. https://doi.org/10.1093/humrep/dev305

Borunova, S. M., Iolchiev, B. S., Abramov, P. N., Badmaev, O. E., Tadzhieva, A. V., \& Ribchenko, A. S. (2017). Effective method of determination of integrity of acromosmosis of spermatozoon in bulls. Veterinary Science and Zootechnics, 4, 30-34.
Bragina, Y. Y., \& Bocharova, Y. N. (2014). Quantitative electron microscopic examination of sperm for male infertility diagnosis. Andrology and Genital Surgery, 15(1), 41-50. https://agx.abvpress.ru/jour/article/view/83?locale=e n_US

Cankut, S., Dinc, T., Cincik, M., Ozturk, G., \& Selam, B. (2019). Evaluation of sperm DNA fragmentation via halosperm technique and TUNEL assay before and after cryopreservation. Reproductive Sciences, 26(12), $1575-1581$ https://doi.org/10.1177/1933719119828096

Carrell, D. T., Liu, L., Peterson, C. M., Jones, K. P., Hatasaka, H. H., Erickson, L., \& Campbell, B. (2003). Sperm DNA fragmentation is increased in couples with unexplained recurrent pregnancy loss. Archives of Andrology, 49(1), 49-55. https://doi.org/10.1080/01485010290099390

Cho, C. L., \& Agarwal, A. (2018). Role of sperm DNA fragmentation in male factor infertility: a systematic review. Arab Journal of Urology, 16(1), 21-34. https://doi.org/10.1016/j.aju.2017.11.002

Choi, H. Y., Kim, S. K., Kim, S. H., Choi, Y. M., \& Jee, B. C. (2017). Impact of sperm DNA fragmentation on clinical in vitro fertilization outcomes. Clinical and Experimental Reproductive Medicine, 44(4), 224. https://doi.org/10.5653/cerm.2017.44.4.224

Deng, C., Li, T., Xie, Y., Guo, Y., Yang, Q. Y., Liang, X., .. \& Liu, G. H. (2019). Sperm DNA fragmentation index influences assisted reproductive technology outcome: A systematic review and meta-analysis combined with a retrospective cohort study. Andrologia, 51(6), e13263. https://doi.org/10.1111/and.13263

Esteves, S. C. (2016). Novel concepts in male factor infertility: clinical and laboratory perspectives. Journal of Assisted Reproduction and Genetics, 33(10), 1319-1335. https://doi.org/10.1007/s10815016-0763-8

Esteves, S. C., Sánchez-Martín, F., Sánchez-Martín, P., Schneider, D. T., \& Gosálvez, J. (2015). Comparison of reproductive outcome in oligozoospermic men with high sperm DNA fragmentation undergoing intracytoplasmic sperm injection with ejaculated and testicular sperm. Fertility and Sterility, 104(6), 1398-1405. https://doi.org/10.1016/j.fertnstert.2015.08.028

Evenson, D. P. (2016). The Sperm Chromatin Structure Assay (SCSA®) and other sperm DNA fragmentation tests for evaluation of sperm nuclear DNA integrity as related to fertility. Animal Reproduction Science, 169, 56-75. https://doi.org/10.1016/j.anireprosci.2016.01.017 
Evenson, D. P., Larson, K. L., \&Jost, L. K. (2002). Sperm chromatin structure assay: its clinical use for detecting sperm DNA fragmentation in male infertility and comparisons with other techniques. Journal of Andrology, 23(1), 25-43. https://doi.org/10.1002/j.1939-4640.2002.tb02599.x

Evgeni, E., Lymberopoulos, G., Gazouli, M., \& Asimakopoulos, B. (2015). Conventional semen parameters and DNA fragmentation in relation to fertility status in a Greek population. European Journal of Obstetrics \& Gynecology and Reproductive Biology, 188, 17-23. https://doi.org/10.1016/j.ejogrb.2015.02.026

Fleming, J. S., Yu, F., McDonald, R. M., Meyers, S. A., Montgomery, G. W., Smith, J. F., \& Nicholson, H. D. (2004). Effects of scrotal heating on sperm surface protein PH-20 expression in sheep. Molecular Reproduction and Development: Incorporating Gamete Research, 68(1), 103-114. https://doi.org/10.1002/mrd.20049

Glinka, M., Gawron, S., Sieroń, A., Pawłowska-Góral, K., Cieślar, G., \& Sieroń, K. (2018). Impact of static magnetic field on the antioxidant defence system of mice fibroblasts. BioMed Research International, 2018. https://doi.org/10.1155/2018/5053608

Isachenko, V., Rahimi, G., Mallmann, P., Sanchez, R., \& Isachenko, E. (2019). Technologies for CryoprotectantFree Vitrification of Human Spermatozoa: Asepticity as a Criterion for Effectiveness. In Vitro Fertilization, 643-654.https://doi.org/10.1111/andr.12414

Kim, G. Y. (2018). What should be done for men with sperm DNA fragmentation?. Clinical and Experimental Reproductive Medicine, 45(3), 101. https://doi.org/10.5653/cerm.2018.45.3.101

Kumar, A., Prasad, J. K., Srivastava, N., \& Ghosh, S. K. (2019). Strategies to minimize various stress-related freeze-thaw damages during conventional cryopreservation of mammalian spermatozoa. Biopreservation and Biobanking, 17(6), 603-612. https://doi.org/10.1089/bio.2019.0037

Kumari, K., Capstick, M., Cassara, A. M., Herrala, M., Koivisto, H., Naarala, J., ... \& Juutilainen, J. (2017). Effects of intermediate frequency magnetic fields on male fertility indicators in mice. Environmental Research, 157, 64-70. https://doi.org/10.1016/j.envres.2017.05.014

Li, D. K., Yan, B., Li, Z., Gao, E., Miao, M., Gong, D., ... \& Yuan, W. (2010). Exposure to magnetic fields and the risk of poor sperm quality. Reproductive Toxicology, 29(1), 86-92. https://doi.org/10.1016/j.reprotox.2009.09.004

Li, M. W., \& Lloyd, K. K. (2020). DNA fragmentation index (DFI) as a measure of sperm quality and fertility in mice. Scientific Reports, 10(1), 1-11. https://doi.org/10.1038/s41598-020-60876-9
Li, Y. X., Zhou, L., Lv, M. Q., Ge, P., Liu, Y. C., \& Zhou, D. X. (2019). Vitrification and conventional freezing methods in sperm cryopreservation: A systematic review and meta-analysis. European Journal of Obstetrics \& Gynecology and Reproductive Biology, 233, 84-92. https://doi.org/10.1016/j.ejogrb.2018.11.028

Liang, X., Mao, Y., Wang, Y., Liu, S., \& Yan, J. (2019). Female age affects the utility of sperm DNA fragmentation in predicting IVF and ICSI outcomes. Reproductive Biomedicine Online, 39(6), 955-962. https://doi.org/10.1016/j.rbmo.2019.09.013

Lusignan, M. F., Li, X., Herrero, B., Delbès, G., \& Chan, P. T. (2018). Effects of different cryopreservation methods on DNA integrity and sperm chromatin quality in men. Andrology, 6(6), 829-835. https://doi.org/10.1111/andr.12529

McCraty, R., Atkinson, M., Stolc, V., Alabdulgader, A. A., Vainoras, A., \& Ragulskis, M. (2017). Synchronization of human autonomic nervous system rhythms with geomagnetic activity in human subjects. International Journal of Environmental Research and Public Health, 14(7), 770. https://doi.org/10.3390/ijerph14070770

Ortiz, I., Dorado, J., Morrell, J., Gosálvez, J., Crespo, F., Jiménez, J. M., \& Hidalgo, M. (2017). New approach to assess sperm DNA fragmentation dynamics: Fine-tuning mathematical models. Journal of Animal Science and Biotechnology, 8(1), 1-9. https://doi.org/10.1186/s40104-017-0155-7

Osman, A., Alsomait, H., Seshadri, S., El-Toukhy, T., \& Khalaf, Y. (2015). The effect of sperm DNA fragmentation on live birth rate after IVF or ICSI: a systematic review and meta-analysis. Reproductive Biomedicine Online, 30(2), 120-127. https://doi.org/10.1016/j.rbmo.2014.10.018

Ozkosem, B., Feinstein, S. I., Fisher, A. B., \& O'Flaherty, C. (2015). Advancing age increases sperm chromatin damage and impairs fertility in peroxiredoxin 6 null mice. Redox Biology, 5, 15-23. https://doi.org/10.1016/j.redox.2015.02.004

Pérez-Crespo, M., Pintado, B., \& Gutiérrez-Adán, A. (2008). Scrotal heat stress effects on sperm viability, sperm DNA integrity and the offspring sex ratio in mice. Molecular Reproduction and Development: Incorporating Gamete Research, 75(1), 40-47. https://doi.org/10.1002/mrd.20759

Sakkas, D., \& Alvarez, J. G. (2010). Sperm DNA fragmentation: mechanisms of origin, impact on reproductive outcome and analysis. Fertility and Sterility, 93(4), 1027-1036. https://doi.org/10.1016/j.fertnstert.2009.10.046 
Salces-Ortiz, J., Ramón, M., González, C., PérezGuzmán, M. D., Garde, J. J., García-Álvarez, O., ... \& Serrano, M. M. (2015). Differences in the ovine HSP90AA1 gene expression rates caused by two linked polymorphisms at its promoter affect rams sperm DNA fragmentation under environmental heat stress conditions. PLoS One, 10(2), e0116360. https://doi.org/10.1371/journal.pone.0116360

Santi, D., Spaggiari, G., \& Simoni, M. (2018). Sperm DNA fragmentation index as a promising predictive tool for male infertility diagnosis and treatment management-meta-analyses. Reproductive Biomedicine Online, 37(3), 315-326. https://doi.org/10.1016/j.rbmo.2018.06.023

Santos, S. I., Sánchez-Dávila, F., Vázquez-Armijo, J. F., Ledezma-Torres, R. A., del Bosque-González, A. S., Palomera, C. L., \& Bernal-Barragán, H. (2015). Changes in sexual behaviour and semen quality associated with age and type of enclosure of Saint Croix rams in different seasons of the year. Italian Journal of Animal Science, 14(4), 3890. https://doi.org/10.4081/ijas.2015.3890

Shamsi, M. B., Imam, S. N., \& Dada, R. (2011). Sperm DNA integrity assays: diagnostic and prognostic challenges and implications in management of infertility. Journal of Assisted Reproduction and Genetics, 28(11), 1073-1085. https://doi.org/10.1007/s10815-011-9631-8
Simon, L., Emery, B. R., \& Carrell, D. T. (2017). diagnosis and impact of sperm DNA alterations in assisted reproduction. Best Practice \& Research Clinical Obstetrics \& Gynaecology, 44, 38-56. https://doi.org/10.1016/j.bpobgyn.2017.07.003

Twigg, J. P., Irvine, D. S., \& Aitken, R. J. (1998). Oxidative damage to DNA in human spermatozoa does not preclude pronucleus formation at intracytoplasmic sperm injection. Human reproduction (Oxford, England), 13(7), 1864-1871. https://doi.org/10.1093/humrep/13.7.1864

Zini, A. (2011). Are sperm chromatin and DNA defects relevant in the clinic?. Systems Biology in Reproductive Medicine, 57(1-2), 78-85. https://doi.org/10.3109/19396368.2010.515704

Zini, A., Bielecki, R., Phang, D., \& Zenzes, M. T. (2001). Correlations between two markers of sperm DNA integrity, DNA denaturation and DNA fragmentation, in fertile and infertile men. Fertility and Sterility, 75(4), 674-677. https://doi.org/10.1016/S0015-0282(00)01796-9 